by 1.6, juiciness - by 1.2, sweetness - by 1.1, acidity - higher by 0.9 and overall rating is higher by 0.9 points (compared with unprocessed fruits).

Keywords: Golden Delicious, cultivating place, rootstock, harvest date, 1Methylcyclopropene, storage, organoleptic evaluation.

\title{
FORMATION OF PHOTOSYNTHESIS SURFACE OF SORGHUM AND SORIZ DEPENDING ON TIMING AND METHODS OF SOWING
}

\author{
S. P. Poltoretsky, Doctor of Agricultural Sciences \\ N. M. Poltoretska, $P h D$ in Agriculture \\ A. A. Yatsenko, Doctor of Agricultural Sciences \\ Uman National University of Horticulture \\ V. M. Burdyga, $P h D$ in Agriculture \\ Podilsky State Agrarian Technical University
}

The results of three-year researches on the improvement of the technology elements of cultivating varieties of sorghum and soriz in the Western Forest-Steppe at the expense of optimization of timing and method of sowing. It is established that the formation of leaf apparatus area of sorghum and soriz depends on the biological characteristics of the variety and the elements of cultivation technologies. The largest area of the photosynthesis surface of the crops was recorded in the panicle earing phase after sowing sorghum and soriz at the average daily temperature of the soil $+12 \ldots+14{ }^{\circ} \mathrm{C}$, wide-row planting with a spacing between lines of 45-37.6 and $39.1 \mathrm{~cm}$ thousand $\mathrm{m}^{2} / \mathrm{ha}$, respectively, of Vinets and Genicheske 209 sorghum varieties and 31.3 thousand $\mathrm{m}^{2} / \mathrm{ha}$ in Perlyna soriz variety.

Keywords: variety, sorghum, soriz, sowing method, leaf-area duration, leafarea index.

Introduction. One of the factors limiting the cultivation of sorghum in the Forest-Steppe in western Ukraine is the lack of data and recommendations regarding the optimal combination of terms and methods of this crop. First of all, this is due to the complexity of the interaction between plants in the middle of cenosis, soil and weather conditions that may occur in the period for which such selection is made. Therefore, considerable attention should be paid to the differentiated approach to determining optimal terms and methods of sowing depending on the needs of plants in specific soil and climatic conditions.

Since till now, there are not many studies on the effectiveness of determining 
terms and methods for sorghum and soriz in Western Ukraine, the study of these issues is relevant.

Actual scientific researches and issue analysis. Despite the large number of scientific publications, the study of the impact of timing and methods on the formation of leaf area is quite controversial. The maximum leaf area of sorghum crops in the experiments of A.S. Kazakov [1] amounted to 40 thousand $\mathrm{m}^{2} / \mathrm{ha}$ in late ripening hybrids. Mid ripening hybrids have for the most the leaf area of 20$34 \mathrm{~m}^{2} / \mathrm{ha}$ which ensures maximum and stable grain yields.

The investigations of Y.F. Olekseenko and V.P. Tokhtarov have established [2] that the smallest leaf area was after sowing in the early periods $\left(4301 \mathrm{~m}^{2} / \mathrm{ha}\right)$; it was slightly larger (5596 and $5309 \mathrm{~m}^{2} / \mathrm{ha}$ ) after sowing in the third and fourth terms, respectively, and it was the largest $\left(5753 \mathrm{~m}^{2} / \mathrm{ha}\right)$ after sowing at the temperature of soil $+12 \ldots+15^{\circ} \mathrm{C}$.

It is also established [3] that the largest leaf area per plant was recorded after sowing in the middle period $\left(1236.9 \mathrm{~cm}^{2}\right)$. At the same time, both early and late sowing caused a decrease in the leaf area.

Similar data are reported by other scientists [4]. Research has found that the largest leaf area of soriz was recorded at its sowing in the middle terms (May 5); it was $21.3-27.7 \mathrm{~m}^{2} / \mathrm{ha}$ in the panicle earing phase depending on genetic features of strains.

According to the results of studies carried out under the conditions of unstable moisture of Right Bank Forest-Steppe [5], the leaf surface of soriz significantly depended on the time of sowing. Thus, in the tillering phase when sowing soriz in the second decade of April the leaf area was $5.4 \mathrm{~m}^{2} / \mathrm{ha}$ and in the next sowing period in 10 days it increased by $1.1 \mathrm{~m}^{2} / \mathrm{ha}$. When sowing in the first decade of May the leaf area has increased by $1.2-1.6$ thousand $\mathrm{m}^{2} /$ ha. However, when sowing in the third decade of May and the first decade of June, the leaf surface decreased in comparison with the earlier sowing terms, but not due to weather conditions, but due to smaller density formed during such periods of sowing. In the stalk-shooting stage, the leaf area has increased significantly but there were indicated trends between the studied variants.

Other researchers point out [6] that the leaf area of sorghum was the largest when sowing on May 15 and amounted to an average of 15.5 thousand $\mathrm{m}^{2} / \mathrm{ha}$. Earlier or later sowing terms resulted in a decrease of this indicator in accordance with $12.5-14.6$ and 15.3 thousand $\mathrm{m}^{2} / \mathrm{ha}$. With the increase of drought in the second half of the growing season, the area of the lower leaves decreases in sorghum plants and under the conditions of severe drought, the area of all leaves decreases.

As for the method of sowing sorghum and soriz which influences the feeding area of one plant and the distance between them in a row, they also affect the formation of the leaf apparatus by crops. Thus, studies have shown $[7,8]$ that the leaf area of sorghum plants depended both on the method of sowing and on the 
biological characteristics of the variety. In particular, the leaf length of Skorospile 65 and Khazine varieties was larger sowing in broad drills and the leaf length of Skorospile 98 and Khazine 33 varieties was larger sowing in narrow drills. It turned out to be the same for both methods of plant placement per unit area for in Zernogradsky 54 and Zernogradsky 53 varieties.

Research by many scientists found that increasing the plant density in a row causes an increase in the leaf area [9]. However, other scientists report [10, 11], overcrowding in a row leads to a decrease in the leaf area of sorghum plants.

The purpose of the study is to create optimal agrotechnical conditions for a complete production process of grain sorghum and soriz plants in Western ForestSteppe due to the optimization of sowing time and method.

Research methods. Field studies to study the effect of sowing time on the growth, development and production of grain sorghum and soriz were conducted in 2014-2016 under the conditions of the Western Forest-Steppe at the experimental field of Podilsky State Agricultural and Technical University.

The schematic course of the research is as follows: a variety (A Factor) Vinets (grain sorghum), Genicheske 209 (grain sorghum) and Perlyna (soriz); the sowing time (B Factor) - the first term (average daily temperature of the soil at the depth of $\left.10 \mathrm{~cm}+10 \ldots+12{ }^{\circ} \mathrm{C}\right)$, the second term $\left(+12 \ldots+14{ }^{\circ} \mathrm{C}\right.$, check variant $)$ and the third term $\left(+14 \ldots+16^{\circ} \mathrm{C}\right)$; the sowing method $(C$ Factor $)$ - usual row (row width of $15 \mathrm{~cm}$ ) and wide row (row width of $30 \mathrm{~cm}, 45$ and $70 \mathrm{~cm}$ ) methods of sowing.

The predecessor of grain sorghum and soriz was winter wheat. After the precursor was harvested, stubble ploughing by disk plough-harrows was at the depth of 6-8 cm. After 3 weeks, plowing was carried out at the depth of $30 \mathrm{~cm}$.

Early in the spring, moisture was closed with heavy harrows and cultivation (the first was to the depth of $10-12 \mathrm{~cm}$, the second one was to $8-10 \mathrm{~cm}$ and the third one was to $3-5 \mathrm{~cm}$ ). The fertilizer system consisted of the introduction of phosphoric and potash fertilizers $\left(\mathrm{P}_{60} \mathrm{~K}_{60}\right)$ under the plowing and nitrogen $\mathrm{N}_{60}$ fertilizers under the first cultivation. Seeds were wiped with Maxim XL 035 FS with the consumption rate of $11 /$ ton to protect against diseases in the initial phases of plant growth. The seeding rate was 220 thousand similar seeds per hectare. The depth of seeding was $4-5 \mathrm{~cm}$.

The registration area was $100 \mathrm{~m}^{2}$. The number of replications was four. The variants were placed by split plot method.

Records, analyzes and observations were conducted in accordance with generally accepted methods $[12,13]$.

The soil of the experimental field, where the research was conducted, is podzolized heavy-loamy which is moisturized by atmospheric precipitation. Groundwater is chemically fresh and lies at a depth of 6-10 $\mathrm{m}$. The arable layer contains $10.8 \mathrm{mg} / 100 \mathrm{~g}$ of light hydrolyzed nitrogen (according to Cornfield), mobile phosphorus (according to Chirikov) - $15.2 \mathrm{mg} / 100 \mathrm{~g}$, exchangeable 
potassium (according to Chirikov) $18.1 \mathrm{mg} / 100 \mathrm{~g}, \mathrm{pH}$ (salt) 6.7 ; the hydrolytic acidity is $1.6 \mathrm{mg} / 100 \mathrm{~g}$ of soil, the base saturation degree is $93.7 \%$, the humus content (according to Tiurin) is $4.74 \%$.

The experimental field is located in the Southern Forest-Steppe part of the Khmelnitsky region and under the conditions of water supply refers to the southern wet agro-climatic region of the region. According to Khmelnytsky Regional Center of Hydrometeorology, during the research, hydrothermal conditions were unstable and significantly different from the average multi-year indicators. This contributed to an objective assessment of the influence of the factors on the progress of growth processes, development and formation of productivity of grain sorghum and soriz.

Research results. According to the results of three years of research, it is found that the leaf area of sorghum and soriz grain depended on the biological characteristics of the variety, timing and method of their sowing (Fig.).

Thus, the largest area of the photosynthesis active surface among studied varieties of sorghum and soriz was formed in Genicheske 209 for all phases of growth and development: tillering phase $\left(6.2-8.3\right.$ thousand $\left.\mathrm{m}^{2} / \mathrm{ha}\right)$, stalk-shooting stage (20.9-23.3 thousand $\mathrm{m}^{2} / \mathrm{ha}$ ), panicle earing stage (36.6-39.1 thousand $\mathrm{m}^{2} / \mathrm{ha}$ ) and full maturity (13.5-15.4 thousand $\mathrm{m}^{2} / \mathrm{ha}$ ), depending on timing and method of sowing.

The level of this indicator was somewhat lower in Vinets variety: 5.9-8.0 thousand $\mathrm{m}^{2} / \mathrm{ha}$ in the tillering phase; $18.4-21.1$ thousand $\mathrm{m}^{2} / \mathrm{ha}$ in the stalkshooting stage; $34.8-37.6$ thousand $\mathrm{m}^{2} / \mathrm{ha}$ in the panicle earing stage; $12.9-15.0$ thousand $\mathrm{m}^{2} / \mathrm{ha}$ in the full maturity, depending on the investigated growing methods.

Significantly the smallest area of the photosynthetic active surface was characterized by Perlyna soriz variety: $5.2-7.1$ thousand $\mathrm{m}^{2} /$ ha in the tillering phase; $16.5-19.6$ thousand $\mathrm{m}^{2} /$ ha in the stalk-shooting stage; $27.9-31.3$ thousand $\mathrm{m}^{2} /$ ha in the panicle earing stage; $11.1-13.6$ thousand $\mathrm{m}^{2} / \mathrm{ha}$ in the full maturity, depending on timing and method of sowing.

Among the studied terms of sowing sorghum and soriz, the most optimal for the formation of the leaf area was the second in which sorghum was sown at an average daily temperature of the soil $+12 \ldots+14^{\circ} \mathrm{C}$, regardless of the method of sowing. Thus, for this timing the leaf area was $6.2-8.3$ thousand $\mathrm{m}^{2} / \mathrm{ha}$ in the tillering phase; $18.0-23.3$ thousand $\mathrm{m}^{2} / \mathrm{ha}$ in the stalk-shooting stage; $30.2-39.1$ thousand $\mathrm{m}^{2} /$ ha in the panicle earing stage; $12.3-15.4$ thousand $\mathrm{m}^{2} /$ ha in the full maturity, depending on the method of sowing and the biological characteristics of the variety. Somewhat lower figures were recorded in the variant in which sowing was carried out later at the average daily temperature of the soil $+14 \ldots+16{ }^{\circ} \mathrm{C}$ : 5.7-7.9 thousand $\mathrm{m}^{2} / \mathrm{ha}$ in the tillering phase; 17.4-22.7 thousand $\mathrm{m}^{2} / \mathrm{ha}$ in the stalk-shooting stage; $29.2-38.7$ thousand $\mathrm{m}^{2} /$ ha in the panicle earing stage; $11.6-$ 14.8 thousand $\mathrm{m}^{2} / \mathrm{ha}$ in the full maturity, depending on the variety and method of sowing. 

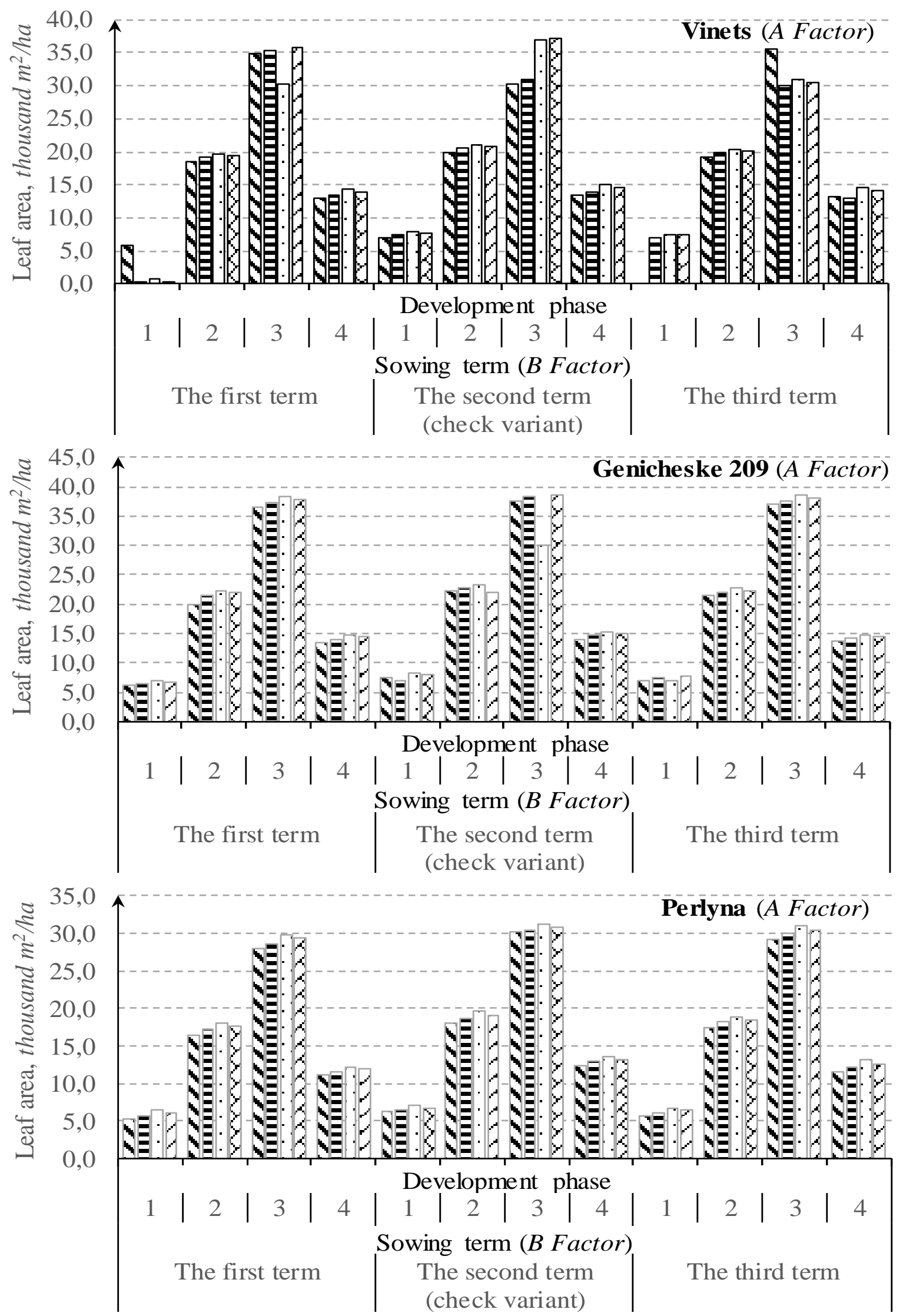

Fig. The leaf area of sorghum and soriz grain depending on timing and method of sowing, 2014-2016.

Notes. $L S D_{05(A)}=0.8 ; L S D_{05(B)}=1.2 ; L S D_{05(C)}=0.7 ; L S D_{05(A B C)}=2.7$.

Development phase: 1 - tillering phase; 2 - stalk-shooting stage;

3 - panicle earing stage; 4 - full maturity. 
However, significantly smaller area of the leaf surface of sorghum was when sowing in early terms at the average daily temperature of the soil $+10 \ldots+12{ }^{\circ} \mathrm{C}$ : $5.2-7.0$ thousand $\mathrm{m}^{2} / \mathrm{ha}$ in the tillering phase; $6.5-22.3$ thousand $\mathrm{m}^{2} / \mathrm{ha}$ in the stalkshooting stage; $27.9-38.4$ thousand $\mathrm{m}^{2} /$ ha in the panicle earing stage; $11.1-14.8$ thousand $\mathrm{m}^{2} /$ ha in the full maturity.

Regarding the method of sowing, it is best shown with a width of rows of 45 $\mathrm{cm}$, where the largest value of the leaf area is $6.4-8.3$ thousand $\mathrm{m}^{2} / \mathrm{ha}$ in the tillering phase; $18.1-23.3$ thousand $\mathrm{m}^{2} /$ ha in the stalk-shooting stage; $29.8-39.1$ thousand $\mathrm{m}^{2} /$ ha in the panicle earing stage; $12.1-15.4$ thousand $\mathrm{m}^{2} /$ ha in the full maturity. All other ways of sowing sorghum are inferior to the above-mentioned variant by indicators of the leaf area.

The largest area of the leaf surface of sorghum and soriz of all the studied variants was marked in Genicheske 209 variety when sowing with a spacing of 45 $\mathrm{cm}$ with an average daily temperature of $+12 \ldots+14{ }^{\circ} \mathrm{C}: 8.3$ thousand $\mathrm{m}^{2} / \mathrm{ha}$ in the tillering phase; 23.3 thousand $\mathrm{m}^{2} /$ ha in the stalk-shooting stage; 39.1 thousand $\mathrm{m}^{2} /$ ha in the panicle earing stage; 15.4 thousand $\mathrm{m}^{2} /$ ha in the full maturity.

The sorghum sowing in the early terms leads to a decrease in the seed similarity, resulting in thinning sprouts. Reducing the number of plants per unit area causes a decrease in the area of the leaf surface of the entire crop. In addition, thinned sprouts contribute to tillering and results in over expenditure of nutrients which also reduces the leaf area per unit sowing. Late sowing is accompanied by a lack of moisture in the soil which also negatively affects the seed similarity and the growth and development of plants in general.

As for the way of sowing sorghum, as it was already noticed earlier, the highest area of photosynthesis surface was when sowing with a width of rows of $45 \mathrm{~cm}$. Reducing width of the rows to 30 and $15 \mathrm{~cm}$ causes an increase in the distance between plants in a row. At the same time, there is a growth of the tillering coefficient. The consequence is an increase in the number of shoots per hectare but they are poorly developed. A similar situation can be observed with a width of rows of $70 \mathrm{~cm}$, when the thickening of plants in a row.

The reason for reducing the leaf area in thickened crops is the increased competition of plants in the cenosis for moisture and nutrients [14]. A significant number of plants per unit area with a large total leaf area rapidly reduce the nutrient reserves and moisture in the soil and as a result, their growth and development are slowed down.

In all variants of the experiment, there is the growth of the photosynthesis area of crops in the tillering, stalk-shooting stages and reaching the maximum in the panicle earing phase. In the future (until the phase of full ripeness) there is a decrease in the leaf area due to the gradual disappearance of the plant leaves.

One of the important indicators characterizing the state of crops is the leaf index which characterizes the situation concerning crop use of land area [15]. Our researches found that this index depended on both biological characteristics of the variety, timing and method of sowing and the phases of development of plants (Table). 


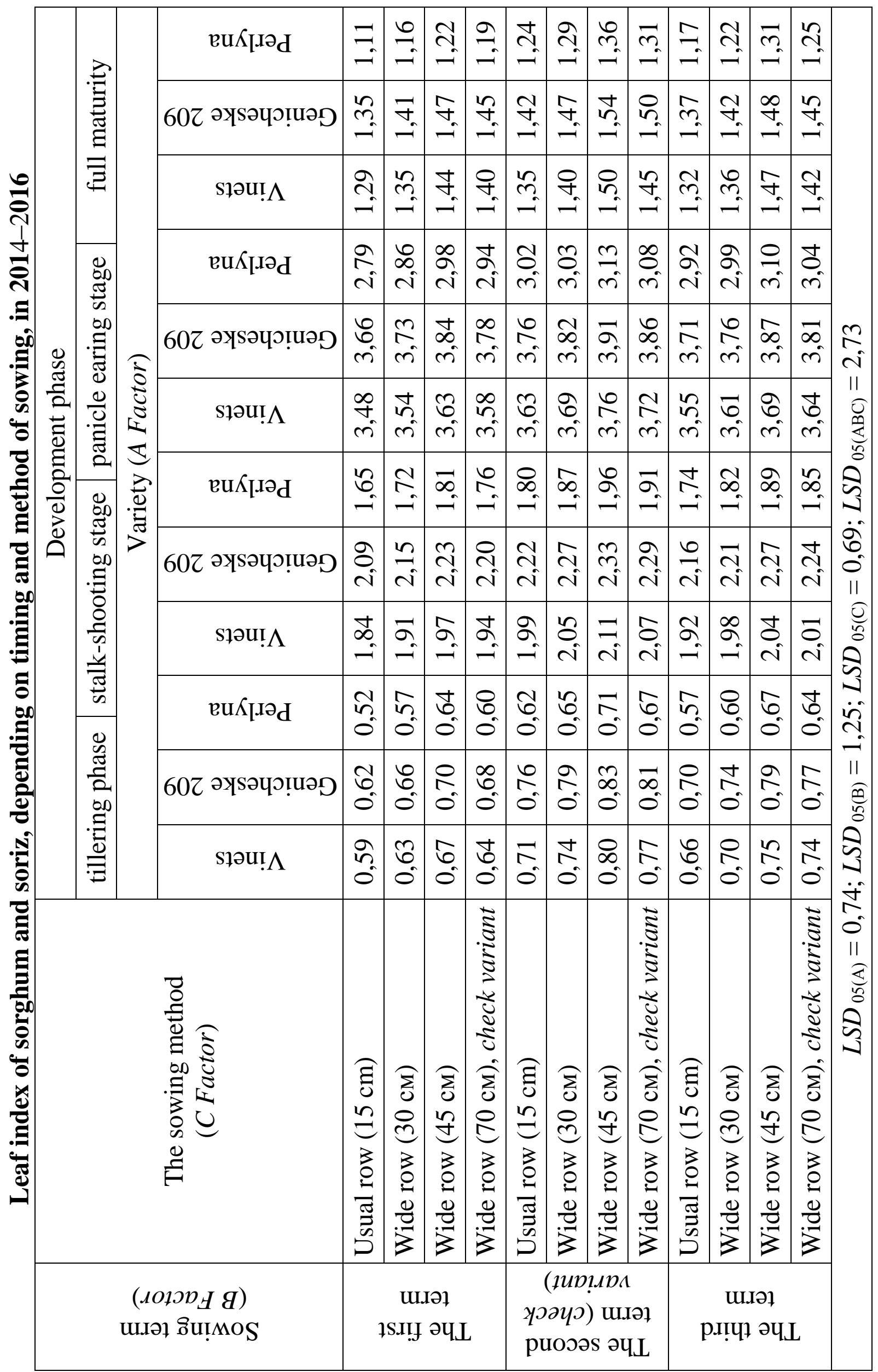


The lowest value of the leaf index was noted in the tillering phase: $0.59-0.80$ of Vinets variety; $0.62-0.83$ of Genicheske 209 ; $0.52-0.71$ in Perlyna variety, depending on timing and method of sowing.

In the next phenological phase there was a significant increase in the value of the leaf index to $1.84-2.11$ of Vinets variety; $2.09-2.33$ of Genicheske 209 and $1.65-1.96$ of Perlyna variety.

The largest value of the leaf index and hence the most complete crop use of the land area was recorded in the panicle earing stage: 3.48-3.76 of Vinets variety; 3.66-3.91 of Genicheske 209 variety and 2.79-3.13 of Perlyna variety. In the phase of full ripeness, the value of the leaf index decreased to 1.29-1.50 of Vinets variety; $1.35-1.54$ of Genicheske 209 variety and 1.11-1.36 of Perlyna variety.

Among the studied sowing time, the largest leaf index was recorded for sorghum and soriz sowing at the average daily temperature of the soil $+12 \ldots+14{ }^{\circ} \mathrm{C}$ (second sowing period): $0.62-0.83$ in the tillering phase; $1.80-2.33$ in the stalk-shooting stage; $3.02-3.91$ in the panicle earing stage and 1.24-1.54 in the full maturity, depending on the variety and the method of sowing. Transfer of sowing at an earlier or later date has led to a significant reduction in the level of this indicator.

Regarding the way of sowing, the best variant from the point of crop use of land area where sorghum was sown with a width of rows of $45 \mathrm{~cm}$. The leaf index at the same time was $0.64-0.83$ in the tillering phase; $1.81-2.33$ in the stalkshooting stage; $2.98-3.91$ in the panicle earing stage and 1.22-1.54 in the full maturity, depending on the time of sowing and biological characteristics of the variety. All other ways of sowing significantly were inferior to this variant of broad sowing.

Conclusions. Formation of the leaf area of sorghum and soriz depends on biological characteristics of the variety and the elements of cultivation technology. The largest area of the photosynthetic surface of crops was recorded in the panicle earing stage when sorghum and soriz sowing at the average daily temperature of the soil $+12 \ldots 14{ }^{\circ} \mathrm{C}$, in a wide row way with a spacing of between $45 \mathrm{~cm}(37.6$ and 39.1 thousand $\mathrm{m}^{2} / \mathrm{ha}$ ) in Vinets and Genicheske 209 varieties and 31.3 thousand $\mathrm{m}^{2} /$ ha of Perlyna variety.

\section{Література}

1. Казакова А. С. Формирование пространственной структуры листового аппарата растений зернового сорго. Селекция, семеноводство и агротехника зерновых и кормовых культур на Дону: сб. науч. тр. Зерноград. 1994. $198 \mathrm{c}$.

2. Олексєнко Ю. Ф., Тохтаров В. П. О сроках посева. Кукуруза и сорго. 1988. № 2. C. $25-26$.

3. Тохтаров В. П. Сроки посева сорго. Кукуруза и сорго. 1986. № 2. С. 
$19-20$.

4. Макаров Л. Х. Соргові культури: монографія. Херсон: Айлант, 2006. $264 \mathrm{c}$.

5. Климович П. В., Січкар А. О., Кононенко Л. М., Климович Н. М. Оптимізація строків сівби соризу в правобережному Лісостепу. Збірник наукових праџь уманського національного університету садівництва. 2012. Випуск 78, Ч. 1. С. 69-75.

6. Колов О.В., Костина Г. И., Буенков А. Ю. Фотосинтетическая продуктивность различных видов сорговых культур. Кукуруза и сорго. 2009. № 5. С. 7-8.

7. Алабушев А. В., Анипенко Л. Н. Состояние и перспективы производства зернового сорго. Кукуруза и сорго. 2005. № 6. С. 7-12.

8. Кобернюк О. Т. Розробка елементів технології вирощування соризу в умовах південної частини Лісостепу західного: автореф. дис...канд. с.-г. наук: 06.01.09. Кам'янець-Подільський. 2012. 20 с.

9. Гринюк І. П. Фотосинтетична продуктивність соргових культур у Правобережному Лісостепу України. Науковий вісник НУБіП України. 2013. Серія: Агрономія. № 183. С. 104-109.

10. Безкровный В. И. Выбор площади питания. Кукуруза и сорго. 1988. № 2. C. 25-26.

11. Рубан О. Г. Оптимальная густота стояния растений. Кукуруза и сорго. 1988. № 3. С. 30-31.

12. Єщенко В. О., Копитко П. Г., Опришко В. П. та ін. Основи наукових досліджень в агрономії: підручник. Київ : Дія, 2005. 288 с.

13. Боровиков В. П., Боровиков И. П. Statistika. Статистический анализ и обработка данных в среде Windows. Москва : Филинъ, 1997. 608 с.

14. Poltoretskyy S. Features of formation of density seed crops of millet's varieties depending on the term and method of sowing in the Right-bank Foreststeppe Ukraine. Episteme czasopismo naukowo-kulturalne. Krakow. 2013. Tom II. P. 187-201.

15. Сторожик Л. І. Вміст хлоропластів у листках рослин сорго цукрового та їх роль в процесі фотосинтезу. Наукові праці Інституту біоенергетичних культур і иукрових буряків: зб. наук. праць. Київ. 2013. Випуск 19. С. 114-118.

\section{References}

1. Kazakova, A. S. (1994). Formation of the spatial structure of leaf apparatus of grain sorghum plants. Selection, seed-growing and agrotechnics of grain and fodder crops on the Don, 1994, 198 p. (In Russian).

2. Olexyenko, Yu. F., Tokhtarov, V. P. (1988). On the timing of sowing. Corn and sorghum, 1988, no. 2, pp. 25-26 (in Russian). 
3. Tokharov, V. P. (1986). Terms of sowing sorghum. Corn and sorghum, 1986, no. 2, pp. 19-20 (in Russian).

4. Makarov, L. Kh. (2006). Organisms of the culture: monograph. Kherson: Ailant, 2006. 264 p. (In Ukraine).

5. Klimovich, P. V., Sichkar, A. O., Kononenko, L. M., Klimovich, N. M. (2012). Optimization of sowing times in the Right-Bank Forest-Steppe. Collection of scientific works of Uman National University of Horticulture, 2012, vol. 78 (1), pp. 69-75 (in Ukraine).

6. Kolov, O. V., Kostina, G. I., Buenkov, A. Yu. (2009). Photosynthetic productivity of different types of sorghum crops. Corn and sorghum, 2009, no. 5, pp. 7-8 (in Russian).

7. Alabushev, A. V., Anipenko, L. N. (2005). The state and prospects of the production of grain sorghum. Corn and sorghum, 2005, no. 6, pp. 7-12 (in Russian).

8. Kobernyuk, O. T. (2012). Development of elements of the technology of cultivation of Soris in the conditions of the southern part of the Western ForestSteppe. Author. of dis. to obtain the degree of Ph.D. Kamenetz-Podolsky, 2012. 20 p. (In Ukraine).

9. Grinyuk, I. P. (2013). Photosynthetic performance of sorghum crops in the Right-bank Forest-steppe of Ukraine. Scientific herald of NUBiP of Ukraine, 2013, no. 183. Available at http://webcache.googleusercontent.com/search?q=cache: WCHSfMvrhfIJ:journals.nubip.edu.ua/index.php/Agronomija/article/download/696/ $667+\& \mathrm{~cd}=1 \& \mathrm{hl}=\mathrm{uk} \& \mathrm{ct}=\mathrm{clnk} \& \mathrm{gl}=\mathrm{ua}$ (in Ukraine).

10. Bezkroven, V. I. (1988). Selection of the area of nutrition. Corn and sorghum, 1988, № 2, pp. 25-26 (in Russian).

11. Ruban, O. G. (1988). Optimal density of plant standing Corn and sorghum, 1988, № 3, pp. 30-31 (in Russian).

12. Jeshhenko, V. O., Kopytko, P. G., Opryshko, V. P. et al. (2005). Osnovy naukovyh doslidzhen v agronomii: Basic research in agronomy. Kyiv: Diya, 2005. 288 p. (In Ukrainian).

13. Borovikov, V. P., Borovikov, I. P. (2003). Statistica. The art of computer data analysis: for professionals Windows. Moscow: Filin, 2003. 608 p. (In Russian).

14. Poltoretskyy, S. (2013). Features of formation of density seed crops of millet's varieties depending on the term and method of sowing in the Right-bank Forest-steppe Ukraine. Episteme czasopismo naukowo-kulturalne, 2013, tom II, pp. 187-201 (in English).

15. Storozhik, L. I. (2013). The content of chloroplasts in the leaves of sugar sorghum plants and their role in the process of photosynthesis. Scientific works of the Institute of Bioenergetic Cultures and Sugar Beet: Sob. sciences works, 2013, vol. 19. pp. 114-118 (in Ukrainian). 
Полторецкий С. П., Полторецкая Н. М., Яценко А. А., Бурдыга В. М. Формирования фотосинтетической поверхности сорго зернового и сориза в зависимости от срока и способа посева

Исследованиями отечественных и зарубежных ученых доказано, что фотосинтетическая продуктивность растений зависит от ассимиляционной поверхности, интенсивности фотосинтеза, суточного прироста вегетативной массы, коэффициента использования солнечной энергии и тому подобное. Поэтому, чем больше площадь листовой поверхности, тем быстрее проходит накопление органического вещества растениями сельскохозяйственных культур, что приводит к увеличению урожайности с единищы площуади их посева. Несмотря на большое количество научных публикачий, по изучению вопроса влияния сроков и способов посева сорго на формирование листовой поверхности посевов, сейчас оно является достаточно дискуссионным. Поэтому, целью исследований было создание оптимальных агротехнических условий для полноценного продукционного процесса растений сорго зернового и сориза в Лесостепи западной за счет оптимизачии срока и способа посева. Методика исследований. Исследования проводились в течение 2014-2016 годов в условиях опьтного поля Подольского государственного аграрно-технического университета, находящегося в южной части Хмельниикой области, которая по теплообеспечённосты и степени увлажненности в течение вегетационного периода относится $\kappa$ южному тепловом агроклиматическому региону. Схема опыта предполагала следующую градации факторов: сорт (фактор А) - Венеи (сорго зерновое), Геническе 209 (сорго зерновое) и Жемчужина (сориз) срок сева (фактор В) - первый срок (среднесуточная температура почвы на глубине $\left.10 \mathrm{cм}+10-12{ }^{\circ} \mathrm{C}\right)$, второй срок $(+12-$ $14{ }^{\circ} \mathrm{C}$, контроль) и третий срок $\left(+14-16^{\circ} \mathrm{C}\right)$; способ сева (фактор C) - обычный строчный (ширина междурядий $15 \mathrm{~cm}$ ) и широкорядный (ширина междурядий $30 \mathrm{cm,} 45$ и 70 см). Площадь учетных участков $100 \mathrm{~m}^{2}$. Повторность опыта четырехкратная. Варианты размещались методом расщепленных участков. Учеты, анализы и наблюдения проводили согласно общепринятых методик. За результатами трехлетних исследований установлено, что формирование площуади листового аппарата сорго зернового и сориза зависит от биологических особенностей сорта и элементов технологии выращивания. Наибольшая площадь фотосинтетической поверхности посевов зафиксирована в фазу выбрасывания метелок при посеве сорго зернового и сориза при наступлении среднесуточной температуры почвы $+12-14{ }^{\circ}$ C, широкорядным способом с шириной междурядий $45 \mathrm{~cm}-37,6$ и 39,1 mыс. $\mathrm{M}^{2} / 2$ а соответственно у сортов сорго зернового

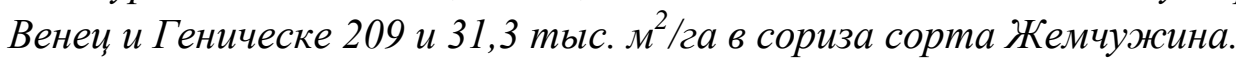

Ключевые слова: сорт, сорго зерновое, сориз, срок сева, способ сева, площяадь листовой поверхности, листовой индекс.

\section{Annotation}

Poltoretsky S. P., Poltoretska N.M., Yatsenko A. A., Burdyga V. M.

Formation of photosynthesis surface of sorghum and soriz depending on the term and method of sowing

Studies of domestic and foreign scientists have shown that the photosynthesis productivity of plants depends on the assimilation surface, photosynthesis intensity, daily increase in the vegetative mass, the coefficient of solar energy use and others. Therefore, the larger the area of 
the leaf surface, the faster the accumulation of organic matter by the plants of agricultural crops is. It leads to an increase in the yield from a unit area of their sowing. Despite the large number of scientific publications, the study of the impact of timing and methods on the formation of leaf area is quite controversial. Therefore, the aim of the research was to create optimal agrotechnical conditions for a full-fledged production process of sorghum and soriz plants in the Western Forest Steppe by optimizing the time and method of sowing. Research methods. The research was conducted in 2014-2016 under the conditions of the experimental field of Podolsk State Agrarian and Technical University, located in the southern part of Khmelnytsky region. For heat and moisture content during the growing season, it refers to the southern thermal agroclimatic region. The experimental design assumed the following gradation factors: variety (factor A) - Vinets (sorghum), Genicheske 209 (sorghum) and Perlyna (soriz); sowing time (factor B) - the first period (the average daily soil temperature at a depth of $10 \mathrm{~cm}$ $\left.+10 \ldots+12^{\circ} \mathrm{C}\right)$, the second term $\left(+12 \ldots+14^{\circ} \mathrm{C}\right.$, check variant) and the third term $\left(+14 \ldots+16^{\circ} \mathrm{C}\right)$; method of sowing (factor $\mathrm{C}$ ) - the usual line (the width of rows between rows is $15 \mathrm{~cm}$ ) and the wide-row (the spacing is $30 \mathrm{~cm}, 45$ and $70 \mathrm{~cm}$ ). The registration area is $100 \mathrm{~m}^{2}$. There are four experimental repetitions. Variants were by the method of split areas. Records, analyzes and observations were conducted according to generally accepted methods. By the results of three years of research, it is established that the formation of the leaf area of sorghum and soriz depends on biological characteristics of the variety and elements of the cultivation technology. The largest area of photosynthesis surface of crops was in the panicle earing stage when sowing sorghum and soriz at the average daily soil temperature $+12 \ldots+14{ }^{\circ} \mathrm{C}$, in a widerow method with a row spacing of $45 \mathrm{~cm}, 37.6$ and 39.1 thousand $\mathrm{m}^{2} / \mathrm{ha}$, respectively, in Vinets and Genicheske 209 sorghum varieties and 1.3 thousand $\mathrm{m}^{2} /$ ha in Perlyna soriz variety.

Keywords: variety, sorghum, soriz, sowing method, leaf-area duration, leaf-area index.

УДК 635.55(477.4)

DOI 10.31395/2415-8240-2018-93-1-118-126

\section{АДАПТИВНА ЗДАТНІСТЬ СОРТІВ САЛАТУ ЦИКОРНОГО ВІТЛУФ В УМОВАХ ПРАВОБЕРЕЖНОГО ЛІСОСТЕПУ УКРАЇНИ}

О. І. Улянич, доктор сільськогосподарських наук

Л. І. Воєвода, аспірант

Уманський національний університет садівництва

Наведено результати вивчення адаптивної здатності сортів Цезар, Воєвода, Конус та Леонардо на ріст, розвиток $і$ урожайність салату циикорного вітлуф. Доведено, що в умовах Правобережного Лісостепу Украйни на чорноземі опідзоленому за урожайністю коренеплодів серед досліджуваних сортів кращим був сорт Воєвода $i$ Леонардо, більша урожайність качанчиків після вигонки була у сорту салату цикорного вітлуф Воєвода.

Ключові слова: салат цикорний, вітлуф, салат, адаптивність, сорт, урожайність, якість. 